\title{
KONSEP GANTI RUGI DALAM PERBUATAN MELAWAN HUKUM DAN WANPRESTASI SERTA SISTEM PENGATURANNYA DALAM KUH PERDATA
}

\section{TITIN APRIANI}

\author{
Fakultas Hukum Universitas 45 Mataram \\ titinapriani91@gmail.com
}

\begin{abstract}
ABSTRAK
Penelitian ini merupakan penelitian pustaka yaitu menggunakan data berupa buku-buku, undang-undang, artikel, jurnal dan literatur lain yang berkaitan denga judul, sedangkan teknik dan pengumpulan data adalah dengan mengumpulkan berbagai ide, teori dan konsep dari berbagai literatur yang menitik beratkan pada proses perbandingan antara dalil-dalil, pasal-pasal atau undang-undang lainnya.

Hasil penelitian dapat ditarik suatu kesimpulan bahwa mengenai perbuatan melawan hukum merupakan hal yang penting dalam bidang hukum perdata. Penerapan konsepsi perbuatan melawan hukum sering kali di persamakan dengan konsepsi perbuatan ingkar janji (wanprestasi). Padahal keduanya merupakan konsepsi yang sangat berbeda satu dengan lainnya, walaupun keduanya bersumber dari perikatan, yaitu konpsesi wanprestasi berasal dari perikatan yang lahir dari perjanjian dan konsepsi perbuatan melawan hukum berasal dari perikatan yang lahir dari undang-undang.
\end{abstract}

\section{Kata Kunci: Ganti Rugi, Melawan Hukum, Wanprestasi}

\section{ABSTRACT}

This research is a library research, which uses data in the form of books, laws, articles, journals and other literature related to the title, while the technique and data collection is to collect various ideas, theories and concepts from various literatures that focus on the process. comparison between arguments, articles or other laws.

The results of the research can be concluded that regarding acts against the law are important things in the field of civil law. The application of the conception of an act against the law is often equated with the conception of breaking a promise (default). Whereas both are very different conceptions from one another, even though both originate from the agreement, namely the conception of default originating from an agreement which is born from an agreement and the conception of unlawful acts originating from an agreement born from a law.

Keywords: Compensation, Against the Law, Default

\section{PENDAHULUAN}

Sebenarnya hukum yang mengatur mengenai ganti rugi perdata ini sudah lama dikenal dalam sejarah hukum, dalam Lex Aquilia salah satu undang-undang yang berlaku di zaman romawi, konsep ganti rugi ini justru dapat terbaca dalam chapter pertamanya, yang mengatur sebagai berikut: jika seseorang secara melawan hukum membunuh seorang budak belian atau gadis hamba sahaya milik orang lain atau binatang ternak berkaki 4 (empat) milik orang lain, maka pembunuhnya harus membayar kepada pemiliknya sebesar nilai tertinggi yang didapati oleh property tersebut tahun lalu. Ganti rugi tersebut menjadi berlipat 2 (dua) jika pihak tergugat menolak tanggung jawabnya. (Justinia, 1979: 71)

Kerugian dalam hukum dapat dipisahkan menjadi dua (2) klasifikasi, yakni Kerugian Materil dan Kerugian Immateril; Kerugian materil Yaitu kerugian yang nyata-nyata ada yang diderita oleh Pemohon. 
Kerugian Imateril: Yaitu kerugian atas manfaat yang kemungkinan akan diterima oleh pemohon di kemudian hari atau kerugian dari kehilangan keuntungan yang mungkin diterima oleh Pemohon di kemudian hari.

Kerugian dalam KUHPerdata dapat bersumber dari Wanprestasi sebagaimana diatur dalam Pasal 1238 Juncto Pasal 1243 dan Perbuatan Melawan Hukum sebagaimana diatur dalam Pasal 1365. Akan tetapi dalam tulisan ini yang akan dibahas yaitu Kerugian dalam Perbuatan Melawan Hukum. Sebagaimana ditegaskan dalam Pasal 1365 KUHPerdata, dalam hal seseorang melakukan suatu Perbuatan Melawan Hukum maka dia berkewajiban membayar ganti rugi akan perbuatannya tersebut, hal yang berbeda dengan Tuntutan kerugian dalam Wanprestasi, dalam tuntutan Perbuatan Melawan Hukum tidak ada pengaturan yang jelas mengenai ganti kerugian tersebut namun sebagaimana diatur dalam Pasal 1371 ayat (2) KUHPerdata tersirat pedoman yang isinya "Juga penggantian kerugian ini dinilai menurut kedudukan dan kemampuan kedua belah pihak, dan menurut keadaan".

Berbicara mengenai perbuatan melawan hukum merupakan hal yang penting dalam bidang hukum perdata. Penerapan konsepsi perbuatan melawan hukum sering kali di persamakan dengan konsepsi perbuatan ingkar janji (wanprestasi). Padahal keduanya merupakan konsepsi yang sangat berbeda satu dengan lainnya, walaupun keduanya bersumber dari perikatan, yaitu konpsesi wanprestasi berasal dari perikatan yang lahir dari perjanjian dan konsepsi perbuatan melawan hukum berasal dari perikatan yang lahir dari undang-undang. ( Sri Redjeki Slamet- Lex Jurnalica Volume 10 Nomor 2, Agustus 2013).

\section{Rumusan Masalah}

1. Bagaimanakah konsep ganti rugi dalam perbuatan melawan hukum dan wanprestasi?

2. Bagaimanakah sistem pengaturan ganti rugi dalam KUHPerdata?

\section{Tujuan Penelitian}

1. Tujuan Obyektif

a. Untuk mengetahui bagaimanakah konsep ganti rugi dalam perbuatan melawan hukum dan wanprestasi di Indonesia.

b. Untuk mengetahui bagaimanakah sistem ganti rugi dalam KUHPerdata sebagai kiblatnya hukum perdata di Indonesia.

2. Tujuan Subyektif

a. Untuk menambah wawasan dan pengetahuan dibidang hukum perdata khususnya dalam wilayah kajian perbuatan melawan hukum dan wanprestasi dalam menerapkan sistem dan konsep ganti rugi.

b. Sebagai bentuk kepedulian guna pengembangan hukum terutama yang menyangkut mengenai sistem dan konsep ganti rugi pada kasus-kasus perbuatan melawan hukum dan wanprestasi yang marak terjadi di masyarakat.

\section{Manfaat Penelitian}

1. Manfaat Teoritis

a. Hasil penelitian ini mampu menyumbangkan pemikiran bagi pengembangan ilmu hukum pada khususnya di bidang hukum keperdataan.

pada umumnya dan

b. Memperkaya referensi dan literatur dalam dunia kepustakaan tentang sistem dan konsep ganti rugi dalam perbuatan melawan hukum dan wanprestasi di bidang hukum keperdataan.

2. Manfaat Praktis

Dapat mengembangkan kemampuan berpikir dan diharapkan hasil dari penelitian ini dapat digunakan sebagai bahan pertimbangan Pemerintah Indonesia supaya lebih meningkatkan kualitas aturan hukum yang akan diterapkan oleh para penegak hukum atau hakim pada kasus-kasus khususnya pada kasus perbuatan melawan hukum dibidang keperdataan.

\section{METODE PENELITIAN}

Pendekatan yang relevan dengan penelitian hukum ini adalah pendekatan undang-undang (statute approach). Pendekatan undang-undang dilakukan dengan mendekati masalah yang diteliti dengan menggunakan sifat hukum yang normatif, karena dalam penelitian ini hukum dikonsepkan sebagai norma-norma tertulis yang dibuat oleh lembaga atau pejabat yang berwenang. Oleh karena itu, pengkajian yang dilakukan hanyalah terbatas pada peraturan perundang-undangan (tertulis) yang terkait dengan masalah yang diteliti. 
Dalam penelitian ini yang digunakan sebagai acuan adalah Kitab Undang Undang Hukum Perdata khususnya Buku Ketiga bagian keempat, mulai dari pasal 1243 sampai sengan 1252. Dalam hal ini untuk ganti rugi tersebut, KUH Perdata secara konsisten untuk ganti rugi digunakan istilah : biaya, rugi, dan bunga. Jenis dan Sumber Bahan Hukum Penelitian. Penelitian ini adalah penelitian kepustakaan (normatif), sehingga bahan dari penelitian ini adalah bahan hukum primer dan bahan hokum sekunder. Sumber data yang digunakan adalah ; a. Bahan hukum primer yang digunakan adalah: Buku Ketiga bagian keempat. b. Bahan hukum sekunder, yaitu bahan yang berisi penjelasan mengenai bahan hukum primer yang terdiri dari buku-buku, artikel, majalah, koran, makalah dan lain sebagainya khususnya yang berkaitan dengan penelitian hukum ini; c. Bahan hukum tersier, yaitu bahan hukum yang memberikan petunjuk atau penjelasan terhadap bahan hukum sekunder yang terdiri dari kamus, dan bahan-bahan dari internet.

\section{HASIL PEMBAHASAN}

\section{Konsep Ganti Rugi dalam Perbuatan Melawan Hukum dan Wanprestasi}

Dari segi kacamata yuridis, konsep ganti rugi dalam hukum dikenal dalam dua bidang, yaitu sebagai berikut: yang pertama konsep ganti rugi karena wanprestasi kontrak, dan yang kedua: konsep ganti rugi karena perikatan berdasarkan undang-undang termasuk ganti rugi karena perbuatan melawan hukum. Banyak persamaan antara konsep ganti rugi karena wanprestasi kontrak dengan konsep ganti rugi karena perbuatan melawan hukum, akan tetapi perbedaannya juga banyak. Ada juga konsep ganti rugi yang dapat diterima dalam system ganti rugi karena perbuatan melawan hukum, tetapi terlalu keras jika diberlakukan terhadap ganti rugi karena wanprestasi kontrak.

Misalnya ganti rugi yang menghukum (punitive damages) yang dapat diterima dengan baik dalam ganti rugi karena perbuatan melawan hukum, tetapi dalam prinsipnya sulit diterima dalam ganti rugi karena wanprestasi kontrak. Ganti rugi dalam bentuk menghukum ini adalah ganti rugi yang harus diberikan kepada korban dalam jumlah yang melebihi dari kerugian yang sebenarnya. Ini dimaksudkan untuk menghukum pihak pelaku perbuatan melawan hukum tersebut. Karena jumlahnya yang melebihi dari kerugian yang nyata di derita, maka untuk ganti rugi menghukum ini sering disebut juga dengan istilah "uang cerdik" (smart money). (Munir Fuady: PT Citra Aditya Bakti: 2013).

Bentuk ganti rugi terhadap perbuatan melawan hukum yang dikenal dalam hukum adalah sebagai berikut:

a. Ganti rugi nominal: jika ada perbuatan melawan hukum yang serius, seperti perbuatan yang mengandung unsur kesengajaan, tetapi tidak menimbulkan kerugian yang nyata bagi korban, maka kepada korban dapat diberikan sejumlah uang tertentu sesuai dengan rasa keadilan tanpa menghitung berapa sebenarnya kerugian tersebut. Inilah yang disebut dengan ganti rugi nominal.

b. Ganti rugi kompensasi: merupakan ganti rugi yang merupakan pembayaran kepada korban atas dan sebesar kerugian yang benar-benar telah dialami oleh pihak korban dari suatu perbuatan melawan hukum. Karena itu ganti rugi seperti ini disebut juga dengan ganti rugi actual. Misalnya ganti rugi atas segala biaya yang dikeluarkan oleh korban, kehilangan keuntungan/gaji, sakit dan penderita, termasuk penderitaan mental seperti stres, malu, jatuh nama baik, dan lain-lain.

c. ganti rugi penghukuman, merupakan suatu ganti rugi dalam jumlah besar yang melebihi dari jumlah kerugian yang sebenarnya. Besarnya jumlah ganti rugi tersebut dimaksudkan diterapkan terhadap kasus-kasus kesengajaan yang berat atau sadis. Misalnya diterapkan terhadap penganiayaan berat atas seseorang tanpa rasa perikemanusiaan.

Dilain pihak kedudukan dari korban dari perbuatan melawan hukum berbeda dengan pihak dalam kontrak yang terhadapnya telah dilakukan wanprestasi oleh lawannya dalam kontrak tersebut, pihak yang telah berani menandatangani kontrak, berarti dia sedikit banyaknya sudah berani mengambil resiko-resiko tertentu, termasuk resiko kerugian yang terbit dari kontrak tersebut. Sehingga ganti rugi yang diberikan kepadanya tidaklah terlalu keras berlakunya. Akan tetapi, lain halnya bagi korban dari perbuatan melawan hukum, yang kadang-kadang datang dengan sangat mendadak dan tanpa diperhitungkan sama sekali. Karena pihak korban dari perbuatan melawan hukum sama sekali tidak siap menerima risiko dan sama sekali tidak pernah berfikir tentang risiko tersebut, maka seyogyanya dia lebih dilindungi, sehingga ganti rugi yang berlaku kepadanya lebih luas dan lebih tegas berlakunya.

Orang sering mencampuradukkan antara gugatan wanprestasi dan gugatan perbuatan melawan hukum. Adakalanya, orang mengajukan gugatan perbuatan melawan hukum. Namun dari dalil-dalil yang dikemukakan, 
sebenarnya lebih tepat kalau diajukan gugatan wanprestasi. Ini akan menjadi celah yang akan dimanfaatkan tergugat dalam tangkisannya. Membedakan antara perbuatan melawan hukum dan wanprestasi sebenarnya gampang-gampang susah. Sepintas, kita bisa melihat persamaan dan perbedaanya dengan gampang. Baik perbuatan melawan hukum dan wanprestasi, sama-sama dapat diajukan tuntutan ganti rugi.

Sementara perbedaannya, seseorang dikatakan wanprestasi apabila ia melanggar suatu perjanjian yang telah disepakati dengan pihak lain. Tiada wanprestasi apabila tidak ada perjanjian sebelumnya. Sedangkan seseorang dikatakan melakukan perbuatan melawan hukum apabila perbuatannya bertentangan dengan hak orang lain, atau bertentangan dengan kewajiban hukumnya sendiri, atau bertentangan dengan kesusilaan.

Beberapa sarjana hukum bahkan berani menyamakan perbuatan melawan hukum dengan wanprestasi dengan batasan-batasan tertentu. Asser Ruten, sarjana hukum Belanda, berpendapat bahwa tidak ada perbedaan yang hakiki antara perbuatan melawan hukum dan wanprestasi. Menurutnya, wanprestasi bukan hanya pelanggaran atas hak orang lain, melainkan juga merupakan gangguan terhadap hak kebendaan.

Senada dengan Rutten, Yahya Harahap berpandapat bahwa dengan tindakan debitur dalam melaksanakan kewajibannya yang tidak tepat waktu atau tak layak, jelas itu merupakan pelanggaran hak kreditur. Setiap pelanggaran hak orang lain berarti merupakan perbuatan melawan hukum. Dikatakan pula, wanprestasi adalah species, sedangkan genusnya adalah perbuatan melawan hukum. Selain itu, bisa saja perbuatan seseorang dikatakan wanprestasi sekaligus perbuatan melawan hukum. Misalnya A yang sedang mengontrak rumah B, tidak membayar uang sewa yang telah disepakati. Selain belum membayar uang sewa, ternyata A juga merusak pintu rumah B. Namun apabila kita cermati lagi, ada suatu perbedaan hakiki antara sifat perbuatan melawan hukum dan wanprestasi. Bahkan, Pitlo menegaskan bahwa baik dilihat dari sejarahnya maupun dari sistematik undang-undang, wanprestasi tidak dapat digolongkan pada pengertian perbuatan melawan hukum.

M.A. Moegni Djojodirdjo dalam bukunya yang berjudul "Perbuatan Melawan Hukum", berpendapat bahwa amat penting untuk mempertimbangkan apakah seseorang akan mengajukan tuntutan ganti rugi karena wanprestasi atau karena perbuatan melawan hukum. Menurut Moegni, akan ada perbedaan dalam pembebanan pembuktian, perhitungan kerugian, dan bentuk ganti ruginya antara tuntutan wanprestasi dan perbuatan melawan hukum. Dalam suatu gugatan perbuatan melawan hukum, penggugat harus membuktikan semua unsur-unsur perbuatan melawan hukum selain harus mampu membuktikan adanya kesalahan yang diperbuat debitur. Sedangkan dalam gugatan wanprestasi, penggugat cukup menunjukkan adanya wanprestasi atau adanya perjanjian yang dilanggar. Kemudian dalam suatu gugatan perbuatan melawan hukum, penggugat dapat menuntut pengembalian pada keadaan semula (restitutio in integrum). Namun, tuntutan tersebut tidak diajukan apabila gugatan yang diajukan dasarnya adalah wanprestasi.(pkbh.uad.ac.id)

\section{Sistem Ganti Rugi dalam KUH Perdata.}

Seperti telah diuraikan di atas, seorang yang melakukan perbuatan melawan hukum maupun wanprestasi wajib mengganti kerugian. Untuk itu kita perlu lebih memahami mengenai tuntutan-tuntutan apa yang dimungkinkan dalam perbuatan melawan hukum maupun wanprestasi. Terlebih dahulu kita akan membahas mengenai tuntutan dalam perbuatan melawan hukum. Dalam pasal 1365 KUHPerdata memberikan kemungkinan beberapa jenis

penuntutan, antara lain (M.A. Moegni Djojodirdjo1976 : 102) :

a. ganti kerugian atas kerugian dalam bentuk uang;

b. ganti kerugian dalam bentuk natura atau pengembalian keadaan pada keadaan semula;

c. pernyataan bahwa perbuatan yang dilakukan dalah bersifat melawan hukum;

d. larangan untuk melakukan suatu perbuatan;

e. meniadakan sesuatu yang diadakan secara melawan hukum;

f. pengumuman daripada keputusan atau dari sesuatu yang telah diperbaiki.

Pembayaran ganti kerugian tidak selalu harus berwujud uang. Hoge Raad dalam Keputusan tanggal 24 Mei 1918 telah mempertimbangkan bahwa pengembalian pada keadaan semula adalah merupakan pembayaran ganti kerugian yang paling tepat. Maksud ketentuan pasal 1365 KUHPerdata adalah untuk seberapa mungkin mengembalikan penderita pada keadaan semula, setidak-tidaknya pada keadaan yang mungkin dicapainya, sekiranya tidak dilakukan perbuatan melawan hukum. Maka yang diusahakan adalah pengembalian yang nyata yang kiranya lebih sesuai dari pada pembayaran ganti kerugian dalam bentuk uang karena pembayaran sejumlah uang hanyalah merupakan nilai yang equivalen saja.

Seorang penderita perbuatan melawan hukum berwenang meminta penggantian natura. Selain daripada haknya untuk meminta ganti kerugian atau untuk menuntut pengembalian pada keadaan semula 
(restitutio in integrum), maka penderita berwenang untuk mengajukan nilai-nilai tuntutan yakni agar pengadilan menyatakan bahwa perbuatan yang dipersalahkan pada pelaku merupakan perbuatan melawan hukum. Dalam hal ini penderita dapat juga mengajukan tuntutan kehadapan Pengadilan agar Pengadilan Negeri memberikan keputusan dieclaratoir tanpa menuntut pembayaran ganti kerugian. Demikian juga penderita dapat menuntut agar Pengadilan Negeri menjatuhkan keputusannya dengan melarang pelaku untuk melakukan perbuatan melawan hukum lagi dikemudian hari. Bilamana si pelaku tetap tidak mentaati keputusan untuk mengembalikan pada keadaan semula, maka si pelaku tersebut dapat dikenakan uang paksa. (Sri Redjeki Slamet- Lex Jurnalica Volume 10 Nomor 2, Agustus 2013)

Kitab Undang-undang hukum perdata yang merupakan kiblatnya hukum perdata di Indonesia, termasuk kiblat bagi hukum yang berkenaan dengan perbuatan melawan hukum, mengatur kerugian dang ganti rugi dalam hubungannya dengan perbuatan melawan hukum dengan 2 (dua) pendekatan sebagai berikut yaitu ganti rugi umum dang anti rugi khusus. Selain dari ganti rugi umum yang diatur mulai dari Pasal 1243 KUHPerdata, KUHPerdata juga mengatur ganti rugi khusus, yakni ganti rugi khusus terhadap kerugian yang timbul dari perikatan-perikatan tertentu. Dalam hubungan dengan ganti rugi yang terbit dari suatu perbuatan melawan hukum, selain dari ganti rugi dalam bentuk yang umum, KUHPerdata juga menyebutkan pemberian ganti rugi terhadap hal-hal sebagai berikut:

a. Ganti rugi semua perbuatan melawan hukum (Pasal 1365).

b. Ganti rugi untuk perbuatan yang dilakukan oleh orang lain (Pasal 1366-Pasal 1367).

c. Ganti rugi untuk pemilik binatang (Pasal 1368).

d. Ganti rugi untuk pemilik gedung yang ambruk (Pasal 1369).

e. Ganti rugi untuk keluarga yang ditinggalkan oleh orang yang dibunuh (Pasal 1370)

f. Ganti rugi karena orang telah luka atau cacat anggota badan (Pasal 1371).

g. Ganti rugi karena tindakan penghinaan (Pasal 1372-1380).

Disamping itu, menurut KUHPerdata ketentuan ganti rugi karena akibat dari perbuatan melawan hukum tidak jauh beda dengan ganti rugi karena wanprestasi. Dalam Pasal 1249 KUHPerdata, ditentukan bahwa penggantian kerugian yang disebabkan karena wanprestasi hanya ditentukan dalam bentuk uang. Namun dalam perkembangannya, menurut para ahli dan yurisprudensi bahwa kerugian dapat dibedakan menjadi dua macam yaitu ganti rugi materiil dan ganti rugi inmateriil. (Asser's 1988:274). Kerugian materiil adalah suatu kerugian yang diderita kreditor dalam bentuk uang/kekayaan/benda, sedangkan kerugian inmateriil adalah suatu kerugian yang diderita oleh kreditor yang tidak bernilai uang, seperti rasa sakit, mukanya pucat, dan lain-lain.(salim HS: Sinar Grafika.2001).

Pedoman selanjutnya mengenai ganti kerugian dalam Perbuatan Melawan Hukum kita bisa lihat dalam Pasal 1372 ayat (2) KUHPerdata yang isinya: "Dalam menilai suatu dan lain, Hakim harus memperhatikan berat ringannya penghinaan, begitu pula pangkat, kedudukan dan kemampuan kedua belah pihak, dan pada keadaan".

Prof. Rosa Agustina dalam bukunya "Perbuatan Melawan Hukum" menerangkan bahwa kerugian akibat Perbuatan Melawan Hukum sebagai "scade" (rugi) saja, sedangakan kerugian akibat Wanprestasi oleh Pasal 1246 KUHPerdata dinamakan "Konsten, scaden en interessen" (biaya, kerugian dan bunga). Kemudian, dalam buku yang sama Prof. Rosa Agustina juga menerangkan bahwa kerugian dalam Perbuatan Melawan Hukum menurut KUHPerdata, Pemohon dapat meminta kepada si pelaku untuk mengganti kerugian yang nyata telah dideritanya (Materil) maupun keuntungan yang akan diperoleh di kemudian hari (Immateril).

\section{PENUTUP}

\section{Simpulan}

1. Mengenai perbuatan melawan hukum merupakan hal yang penting dalam bidang hukum perdata. Penerapan konsepsi perbuatan melawan hukum sering kali di persamakan dengan konsepsi perbuatan ingkar janji (wanprestasi). Padahal keduanya merupakan konsepsi yang sangat berbeda satu dengan lainnya, walaupun keduanya bersumber dari perikatan, yaitu konpsesi wanprestasi berasal dari perikatan yang lahir dari perjanjian dan konsepsi perbuatan melawan hukum berasal dari perikatan yang lahir dari undang-undang.

2. Ada dua sebab timbulnya ganti rugi, yaitu ganti rugi karena wanprestasi dang anti rugi karena perbuatan melawan hukum. Ganti rugi karena wanprestasi diatur dalam Buku III KUHPerdata, yang dimulai dari Pasal 1243 KUHPerdata s/d Pasal 1252 KUHPerdata, sedangkan ganti rugi karena perbuatan melawan hukum diatur dalam Pasal 1365 KUHPerdata. 


\section{Saran}

Mengenai perbuatan melawan hukum merupakan hal yang penting dalam bidang hukum perdata, sehingga penting untuk memahami landasan hukum perdata dalam menegakkan hukum supaya tidak dianggap wanprestasi.

\section{DAFTAR PUSTAKA}

Mujahidin Ahmad. (2007). Peradilan Satu Atap di Indonesia. Bandung : PT Refika Aditama.

Sutiyoso Bambang \& Hastuti Sri PS. (2005). Aspek-Aspek Perkembangan Kekuasaan Kehakiman. Yogyakarta : UII Press Yogyakarta.

Kansil C. S. T. \& Christine S. T. S. Kansil. (2000). Pengantar Ilmu Hukum Semester Ganjil. Jakarta : Balai Pustaka.

Fuady Munir. (2013). Perbuatan Melawan Hukum, Pendekatan Kontemporer, Cetakan ke IV. Bandung: PT.Citra Aditiya.

Kitab Undang-undang Hukum Perdata.

Abdulkadir Muhammad. (2000). Hukum Acara Perdata, Cetakan ke VII. Bandung: PT. Citra Aditya Bakti.

Reglement Buiten Gewesten (RBG) atau Reglement Daerah Sebrang (RDS).

Reglemen Indonesia yang dibaharui Staatsblad 1941, Nomor 44 (RIB).

Salim HS. (2001). Pengantar Hukum Perdata Tertulis (BW). Jakarta : Sinar Grafika.

Redjeki Sri S. Lex Jurnalica Volume 10 Nomor 2, Agustus 2013.

Susanto F Anthon. (2015). Penelitian Hukum Transformatif-Partisifatoris (Fondasi Penelitian Kolaborasi dan Aplikasi Campuran (Mix Method) dalam Penelitian Hukum. Malang: Setara Press.

Subekti. (1994). Pokok-Pokok Hukum Perdata. Cetakan ke XXVI. Jakarta: PT. Intermasa.

Taufik Makarao Moh. (2004). Pokok-Pokok Hukum Acara Perdata. Jakarta : PT. Rineka Cipta.

https://www.hukumonline.com/klinik/detail/ulasan/lt4da27259c45b9/di-mana-pengaturan-kerugian-

konsekuensial-dalam-hukum-indonesia-/

http://pkbh.uad.ac.id/975/ 